\title{
Development of a toolkit for a mentoring program
}

\author{
Harold Tinoco-Giraldo \\ Estudiante Doctorado Programa \\ Formación del Conocimiento \\ Universidad de Salamanca/ \\ Salamanca, Spain \\ htinocogiraldo@usal.es
}

\author{
Eva María Torrecilla Sánchez \\ Profesora Ayudante Doctor \\ Facultad de Educación \\ Universidad de Salamanca/ \\ Salamanca, Spain \\ emt@usal.es
}

\author{
Francisco J. García Peñalvo \\ Profesor Titular \\ GRIAL Research \\ Universidad de Salamanca/ \\ Salamanca, Spain \\ fgarcia@usal.es
}

\begin{abstract}
The mentoring kit for a mentoring program provides the mentors with the necessary resources and tools to help to mentees and teams to understand, apply and integrate their strengths in their respective roles. The tools of the kit offer a working model with the mentee to develop an effective strategy that improves his/her performance through development based on strengths. One of the most effective methods for managing and developing talent within students are mentoring programs. These programs provide a vehicle in which knowledge and wisdom is shared while creating an environment for learning and growth. Novice mentors could benefit from a toolkit to help structure effective mentoring programs. This article describes such a toolkit to provide mentors with the necessary resources and tools to help mentees and teams to understand, apply and integrate their strengths in their respective roles. The objectives of this toolkit are: 1. Deliver models and structures so that the mentee has the ability to: - Develop transformational, theoretical and experiential learning processes. - Develop, evaluate and optimize your resources to function with greater creativity, prominence, leadership and proactivity. 2. Stimulate the development of skills that provide innovative perspectives. 3 . Learn to apply the tools and skills acquired in the educational field to: - Understand and diagnose situations in context. Develop intervention plans with his/her mentor adjusted to the needs and expectations of themselves. - Generate spaces for the identification of barriers and conflicts in his/her processes. Stimulate actions to overcome challenges or opportunities. Effective accompaniment of the mentees to reach their goals. Additionally, the tools included in the kit offer a working model for the mentee to develop an effective strategy that improves his/her performance through development based on strengths. This article presents the importance of the use of mentoring
\end{abstract}

tools, under the guidelines of the mentoring toolkit design. This article presents the importance of the use of mentoring tools, under the guidelines of the mentoring toolkit design. This paper reflects simple tools that can be used in a systematic way so that in the mentoring process the participant can perform the most difficult task of all, that of investigating themselves and at the same time the mentor can count on valuable data to be able to facilitate the work. Future research will focus on the evaluation of the toolkit.

\section{KEYWORDS}

Mentoring, toolkit, professional and academic capability, academic development.

\section{Introduction}

People reach their full potential when they can use their best academic and work talents every day. Mentors recognize how to leverage the talents of each person to prepare individuals for success [8], to help to achieve their performance objectives and meet their goals.

The initial aspects of mentoring were aimed at personal or professional development. Resorting to motivation, reflection and analysis strategies, the mentor focused on improving selfesteem and redirecting the goals of their mentees, regardless of field or discipline. In fact, mentoring has traditionally worked best following this personal approach based upon leveraging the unique strengths of each individual, this helped achieve important advances that catapulted the growth and development of mentees as and was essential in many areas of personal growth. In the academic arena, for example, students who 
occasionally lose sight of their objectives or who need reinforcement of their self-esteem and their talents, turn to their mentors for assistance and direction. There are many approaches to mentorship, but in general it is an act of self-knowledge and personal evaluation.

Mentoring is a widely-recognized best practice and as a powerful strategy for developing talent by encouraging mentees to take responsibility for their growth and development [32]. Mentees have the opportunity to develop academic and career goals, learn new skills, expand their knowledge, diversify their experience, and grow their networks with the help of a mentor [46]. Research has also shown that mentoring can improve employee morale and enhance retention, especially within sponsorship positions, while lack of employee access to mentoring was first on a list of barriers to advancement [9].

Mentoring helps individuals affirm and structure their personalities in pro to achieve good results [13]. It contributes methodology and experience, but its main purpose is to help mentees actively participate in their personal and professional development by mirroring aspects of performance of their mentors. Mentoring activities seek to achieve the proposed goals using individuals own resources and talents, which help them develop a competitive advantage for participants. In the competitive modern academic world, mentoring is becoming increasingly important [47].

Keeping this in mind, using tools that support mentoring will help to achieve the mentees goals in the mentoring process. These goals include encouragement and support and academic responsibility, improvement of the quality of the mentees academic work product, enhancement of leadership capacity, turning academic failure into growth, taking advantage of the opportunities, overcoming weaknesses and more. A toolkit for a mentoring program can guide participants through their own mentoring process, outlaying expectations, roles and responsibilities, setting goals and objectives, and clarifying the style of their own mentoring relationship [5].

The main purpose of this paper is to establish how the development of a mentoring toolkit supports, develops and impacts the performance and results in a mentoring program. The paper presents how mentoring has been used in educational field and the importance of a mentoring toolkit. It describes and outline each mentoring stage and the key information for the corresponding tools.

\section{Theoretical Framework}

\subsection{The Power of Mentoring}

Mentoring has an important responsibility in developing talent and enhancing professional and academic capability [34]. Mentoring partnerships engage in a broad spectrum of learning activities such academic and career development and/or personal coaching, academic project reviews, attending conferences or meetings together, sharing books, links and information, networking, field trips, and many others [28].
Mentoring is focused on short and longer-term development goals. This leads us to what is often perceived as an important paradox in mentoring: mentors listen to mentees and offer solutions. In fact, many people need some time rationalizing and explaining their ideas to a mentor to more fully understand and accept that the skills or know-how mentoring is more about the fostering of a dialogue rather than focus on the mentor solving the mentee's problems or offering ideas to get what they want [24].

Essentially, the art of mastering mentoring is the art of subtly creating a learning environment for the mentee to help to solve their own problems, develop their own ambitions and enabling savvy individuals to collaborate and find solutions.[19]. It could be misleading to present a broad set of tools to help to achieve mentors' goal, without understanding mentoring skills.

True mentoring, however, tries to create an environment for the mentee to develop in his/her own path utilizing his/her own capabilities [3], without being hampered by mentoring that is simply providing answers that could disturb the personal exploration and development that help mentees grow. A mentormentee relationship is based in activities that build trust, support a mutually collaborative relationship, track progress, and prevent complications that can detour this relationship.

The mentor is, in most cases, a person with more professional and academic experience in the area of study or the desired career path of the mentee. Mentoring is about sharing knowledge that has been built from within, tailor-made to the history, challenges, people and their own educational culture [2].

In a mentoring relationship, mentor and mentee explore and develop strategies that fit their own internal and external environment [14]. Mentees can ask the "why question" behind important strategic decisions, thereby taking a leadership role and driving change. Mentors share their unique experience and personal path they took and the barriers they had to overcome, allowing mentees find their way more easily [44]. In the meantime, mentors are challenged in their own thinking and get new perspectives and ideas.

\subsection{The Role of Mentoring in Higher Education}

The mentoring process requires four necessary elements: the mentor, the mentee, the periodic meetings and the individual development plan.

The responsibilities, tasks and qualities of a mentor are the ability to serve, its insight and ability to analyze; patience, impartiality, support for their mentees [21], interest in carrying out their work; be a good listener (know how to listen), be perceptive, conscious, objective and responsible; his capacity for expression, knowing how to transmit and communicate his ideas clearly and ensure that he has been understood [26]; be open to dialogue, build trust and credibility [33], have the knowledge, skills and experience to perform your task efficiently and effectively [10].

Due to the significant commitment and attributes necessary to be an effective mentor, the question arises whether someone can become an effective academic mentor to their mentees? It is not necessary to possess every quality or use them 
simultaneously. A person who possesses some of these qualities and who is willing to empower mentees can be a good candidate [4]. The most important attribute is their ability to serve and the interest they demonstrate in helping and guiding others identify and optimize their own skills they possess.

Through the mentoring process, further knowledge and experience essential to the mentoring competencies will be developed along the way. On the other hand, the mentee must actively lead as the main actor in a mentoring process, and through the help of the mentor, increase their greatest strengths and knowledge to find for themselves the answers that they need to more successfully achieve their academic goals and objectives, maximize their potential and appreciate their full range of possibilities [22].

Each mentee has a unique personality and own academic circumstances that result in ways of behaving, thinking and feeling that are different from each other, which is why there is no single mentoring academic model [36]. The mentee must possess the adequate psychological maturity that leads him/her to perceive his or her own unique capabilities, be able to make relevant decisions in conditions of uncertainty and to face the complex educational situations that arise as they develop their own professional knowledge and capabilities [49]. The success of these developments, also depends on a good pedagogical model, and should be based on the principles of: active learning, collaborative learning, autonomous learning, varied options of interactivity, synchronous and asynchronous communication relevant and creative activities or tasks continuous assessment. [48].

The cognitive ability also determines how the mentee faces the circumstances of his/her environment, through the interpretation of his/her own learning scenarios in different ways [20]. The importance of the perception, the sensation, attention and memory in the mentee acts as a filter of how mentees perceive their reality, through which mentees interpret and respond to the experiences and expectations they face academically and professionally.

Anther necessary element is that of time management and the ideal setting for meetings with the mentor. A mentoring process requires an analysis of the initial situation and from there it is necessary to design a strategy. The strategy is formed by leveraging various resources and techniques to guarantee the usefulness of the mentoring experience to obtain the desired results [18]. Such concepts must be formulated during in the meetings of the mentor with the mentee, which become the basis of an effective mentoring process.

There are different types of mentoring sessions depending on their purpose [15]:

- Initial mentoring sessions, during which shared knowledge between mentor and mentee are established as well as the sense of confidentiality and mutual respect

- A session to establish shared objectives between participants
- A session to design the individual development plan, which includes a commitment on the part of the mentee to achieve the desired objectives.

- A session to analyze the mentee's potential.

- A session focused on follow-up and feedback

The development plan is a guide in which the most important actions of a mentoring process are prioritized in order to meet certain objectives or goals. The development plan should detail the specific activities to be carried out, establishing dates for expected milestones and necessary resources to be able to carry out these actions [11]. It also serves to identify which actions are and are not likely to help achieve the desired results which help make the necessary changes to help the mentee achieve the objectives more quickly.

\subsection{Type of Academic Mentors}

The mentor can be a specialist in the functionality of academic teams and student development, and can provide specific solutions to a problem, also, he/she allows his/her mentors to find solutions for themselves, providing them with the tools to find a solution [43].

Mentors focus on strengths and weaknesses and know that there are not necessarily good or bad strategies, rather the ability to apply one solution or another depending on the situation [23]. What can be a good approach or a good strategy for one can be bad for another.

Currently, academic mentoring is emerging as one of the most powerful tools to solve these two fundamental questions that any individual and academic institutions poses: "What do I want / What do we want?" "How best to get it?". It is based on the premise that "the mentee has all the resources (or can get them by himself) to achieve his goals" [17].

The academic mentor only acts as a facilitator, motivating the mentee through the use of tools such as emotional intelligence [25], language, work and live examples, practical activities and some leadership and neuroscience tools [31]. It is necessary to clarify that there are different styles of mentors in academia, each characterized by aspects of the personality of the individual who serves as mentor. The following are the most popular types of academic mentors:

- Mentor communicator. His greatest skill is to build open and accessible relationships with his/her mentees. Key resources include effective and continuous communication and open interactions with mentees. This type of mentor is dedicated to serve his/her mentees, working alongside with them continuously [7].

- Mentor coach: Seeks to take an active role in the development of mentees' academic long-term projects and goals. It offers informal guidance about scholarly issues and the development solutions. Its key resources are based on effective and continuous communication with his/her mentees offering long-term guidance and insights about the school and professional orientation [45]. This style is evidenced through communications about professional issues and decisions, pursuing the interest of the mentees. 
- Mentor tutor: $\mathrm{He} / \mathrm{she}$ focuses on the practical and academic tasks and only shares his/her knowledge on technical specialty. Among his/her resources are technical competences, the transfer of skills and knowledge and the proper development of tasks [35]. This style of mentor is considered a specialist in his/her field, grants opportunities for the learning of others, provides opportunities for mentees to practice new skills.

- Model mentor: He /she is an example to follow, therefore, is inspiring [29]. His/her main talent is the ability to inspire and motivate positive thinking aimed at success and not failure.

\subsection{Importance of a Toolkit in the Dynamics of Mentoring Program}

Mentoring is a discipline that allows us to uncover new and deeper abilities that help transform individuals and serve as a guide to improving some aspect of their life, whether personal or professional. The techniques listed and explained below are fundamental in the mentor's skill set. They are among the most valuable mentoring tools. Unfortunately, they are often undervalued or simply used to start a mentoring process and abandoned too soon by the average mentor who quickly gets into the job and asks too many questions centered on the mentee [12].

When these techniques are observed or used, they sometimes seem only focused on the mentee talking about their problems or ambitions [30]. However, they contribute to the mentor acquiring all the information necessary to understand the mentees' problems [6], in the same way that a competent journalist would interview a person to obtain the greatest amount of information before writing a good article.

A mentor does not necessarily focus on the content of the mentee's challenges, but rather on the mentee as a person and on the unveiling of the mentees reference structure. This may include issues such as the mentees belief system, his/her perceptions, values, basic ideas, mental disposition, emotional intelligence, limits, potential, thought patterns, self-fulfilling forecasts, etc [39]. When it comes to using the mentor set of skills, it is very important to understand that mentoring is focused on who mentees are and how they are relating to their own problems or ambitions.

These techniques, skills and tools ultimately serve to create the matrix or environment in which the mentee will expose, explore, develop, create and mature his/her personal relationship with the mentor and, more importantly, his/her own relationship with him/herself [27]. In this sense, these skills and techniques serve the ultimate goal of the mentor which is to be fully present and to be almost transparent to the mentee so that he/she can focus on his/her problems or search without obstacles.

Each tool must be appropriate for a specific situation according to the needs and the agenda of the mentee and the stage in the mentoring process at which the mentor and mentee have established. It is important to emphasize that each participant in a mentoring relationship is unique [41], therefore, there are specific tools and techniques applicable to specific and different issues in each process.

The tools and techniques used in a mentoring session can be used for different purposes, among which are: evaluating mentee's needs, know the mentee better, increase mentee's selfawareness, develop and enhance personal skills, and challenge self-limiting beliefs and attitudes [1].

\section{Toolkit Overview}

This proposal is framed with the following work plan:

\subsection{Toolkit Design}

The toolkit is designed to streamline the process of defining and achieving goals in three stages of a mentoring program: Getting Acquainted, Setting Goals and Objectives and Assessing and Closing.

Table 1. Stages of a mentoring program and tools

\begin{tabular}{|c|c|c|}
\hline & Process/Goals & Tools \\
\hline \multicolumn{3}{|c|}{ Getting Acquainted } \\
\hline & $\begin{array}{l}\text { Getting to know each other } \\
\text { as individuals. }\end{array}$ & $\begin{array}{l}\text { Activity } 1 \mathrm{~A} \text { : Getting acquainted with } \\
\text { your partner. }\end{array}$ \\
\hline & $\begin{array}{l}\text { Sharing and agreeing on } \\
\text { expectations. }\end{array}$ & $\begin{array}{l}\text { Activity 1B: Mentoring expectations } \\
\text { thought-starter list. }\end{array}$ \\
\hline & $\begin{array}{l}\text { Clarifying roles and } \\
\text { responsibilities and how } \\
\text { we can help each other. }\end{array}$ & $\begin{array}{l}\text { Activity } 1 \mathrm{C} \text { : Mentoring expectations } \\
\text { worksheet. }\end{array}$ \\
\hline & $\begin{array}{l}\text { Gaining a mutual } \\
\text { understanding of each } \\
\text { other's communication and } \\
\text { learning styles. }\end{array}$ & Activity 1D: Learning styles worksheet. \\
\hline E. & $\begin{array}{l}\text { Establishing what must be } \\
\text { done before developing a } \\
\text { contract. }\end{array}$ & $\begin{array}{l}\text { Activity 1D: Communication style } \\
\text { assessment. }\end{array}$ \\
\hline \multicolumn{3}{|c|}{$\begin{array}{ll}\text { 2. } & \text { Setting Goals and Objectives } \\
\text { - } & \text { Develop and document explicit agreements on: }\end{array}$} \\
\hline F. & $\begin{array}{l}\text { Development goals, scope, } \\
\text { time frame }\end{array}$ & $\begin{array}{l}\text { Activity 2A: Review mapping your career } \\
\text { assessment results. Understand your } \\
\text { mentee's skills and interests. }\end{array}$ \\
\hline & $\begin{array}{l}\text { Establishing roles and } \\
\text { expectations }\end{array}$ & Activity 2B: Goal setting exercise. \\
\hline \multicolumn{3}{|c|}{ - $\quad$ Action plan: } \\
\hline $\mathrm{H}$. & $\begin{array}{l}\text { Develop alternative } \\
\text { solutions or approaches to } \\
\text { meet development need. }\end{array}$ & $\begin{array}{l}\text { Activity } 2 \mathrm{C} \text { : Tips for giving and receiving } \\
\text { feedback. }\end{array}$ \\
\hline I. & $\begin{array}{l}\text { Identify learning activities } \\
\text { to conduct. }\end{array}$ & $\begin{array}{l}\text { Activity 2D: Mentoring session } \\
\text { preparation worksheet. }\end{array}$ \\
\hline $\mathrm{J}$. & $\begin{array}{l}\text { Develop action or } \\
\text { implementation plan. }\end{array}$ & Activity 2E: Mentoring session debriefs. \\
\hline \multicolumn{3}{|c|}{ 3. Assessing and Closing } \\
\hline & $\begin{array}{l}\text { Assess whether } \\
\text { development goals have } \\
\text { been met. }\end{array}$ & $\begin{array}{l}\text { Activity } 3 \mathrm{~A}: \text { Mid-point check - } \\
\text { conference call and electronic survey. } \\
\text { Complete personal and professional } \\
\text { accomplishments tool. }\end{array}$ \\
\hline & $\begin{array}{l}\text { Provide feedback to one } \\
\text { another on the } \\
\text { effectiveness of the } \\
\text { partnership. }\end{array}$ & $\begin{array}{l}\text { Activity 3B: Participate in experience } \\
\text { exchange celebration. Complete final } \\
\text { online evaluation of mentoring } \\
\text { relationship and process. }\end{array}$ \\
\hline
\end{tabular}


The main purpose is to increase the mentee's conscience and responsibility, to generate a high-level direct action in a mentoring process. Table 1 shows us the stages and tools designed for each process.

This toolkit provides a process that enables effective mentoring relationships, provides access to mentors, tools and resources, evaluates results for mentors and mentees, and incorporates mentoring best practices into the academic processes. Following are the key elements of this toolkit:

- Mentor and mentee agree on the skills and knowledge a mentee wants to gain. Mentor and mentee agree on how often to meet within an academic semester period and together they create a realistic development plan.

- $\quad$ The mentee drives the partnership by scheduling meetings, actively soliciting feedback and performing related projects to develop the targeted skills between meetings with the mentor.

- The mentor's role is to be a guide, advisor, coach, and confidant. The mentor helps assess the mentee's skills, gives feedback, suggests resources, and coaches on specific skills.

\subsection{Toolkit Goals}

The mentoring toolkit helps to:

- Mentor individuals to use their strengths and maximize their talent to achieve the results of desired performance.

- Provide mentors with techniques in the use of strength-based development to address challenges specific related to performance.

- Help mentees discover, develop and use their unique talents for greater commitment on different situations

- $\quad$ Provide mentees with strategies to maximize their individual talents and collectives in order to improve team performance and productivity.

\subsection{Mentoring Stages, Goals and their Tools}

Stage 1: Getting Acquainted with Your Rartner.

Goal A: Getting to know each other as individuals.

Your Partner's Information - Activity 1A: It is a powerful and creative tool for personal and team development. The method invites the mentee to free themselves from the fixed modalities of thought and habitual solutions, enabling a different point of view, opening up new possibilities for change, expansion and growth.

Goal B: Sharing and agreeing on expectations.

Mentoring Expectations thought-starter list - Activity 1B: This activity helps to get a brief knowledge about participants using the process of writing, clarifying, and agreeing on expectations. It is a valuable and powerful tool for helping the relationship to be mutually satisfying.

Goal C: Clarifying roles and responsibilities and how we can help each other.

Mentoring Expectations Worksheet - Activity 1C: This tool helps to recognize the mentoring relationships expectations and allows mentors to have a clear communication with his/her pair.
Goal D: Gaining a mutual understanding of each other's communication and learning styles.

Learning styles worksheet. - Activity $1 D$ : This activity is to determine mentee's preferred method of learning or solving problems.

Table 2. Your Partner's Information - Activity 1A

\begin{tabular}{|l|l|}
\hline Name & Location \\
\hline $\begin{array}{l}\text { Personal Background: Personal and/or career history, experiences, core } \\
\text { values, personal mission statement, others. }\end{array}$ \\
\hline $\begin{array}{l}\text { Goals: Personal, career, progress toward achieving, obstacles in achieving, } \\
\text { others. }\end{array}$ \\
\hline $\begin{array}{l}\text { Perspectives: Keys to success, development needed, your motivations, your } \\
\text { commitments, etc. }\end{array}$ \\
\hline $\begin{array}{l}\text { Skills and Abilities: What do you do best, what do you want to do more of, } \\
\text { what you want to learn, etc. }\end{array}$ \\
\hline Hobbies or Interests: \\
\hline Additional questions to help you better understand your partner: \\
\hline
\end{tabular}

Goal E: Establishing what must be done before developing a contract.

Communication style assessment. - Activity 1E: This tool helps to determine the style that pair should use most when communicating with each other. Recognizing the act of communication preference, participants can create ways to work in different situations, express themselves with clear mind and be honest with feelings and personality characteristics (Table 3.).

Stage 2: Setting goals and objectives.

Goal F: Development goals, scope, time frame.

Review mapping your career assessment results. Understand your mentee's skills and interests- Activity 2A: This tool helps to plan and to reflect on mentees' personal goals and prepare responses to the following questions which they will discuss with their mentors: What are the mentees' most dominant personality types? What kind of work environments suit the mentees best? What are the most important work values?

Goal G: Establishing roles and expectations.

Goal setting exercise- Activity 2B: Mentees are responsible for creating their own development plans. During the mentoring process, mentee and mentor begin fleshing out the objectives, steps, resources needed, timeline, and expected results. The development plan is used to drive the mentee/mentor partnership.

Goal H: Develop alternative solutions or approaches to meet development need.

Tips for giving and receiving feedback - Activity 2C: Mentoring relationship requires dedication and strong commitment. To gain the most out of a mentoring relationship, participants agree to mentoring promises and commitments to each other.

Goal I: Identify learning activities to conduct.

Mentoring session preparation worksheet - Activity 2D: This tool is an action plan roadmap that allows the mentee to define which objectives want to achieve in the long term. These actions are divided into small stages or microobjectives. A series of organized stages are designed, 
specifying the deadlines and resources necessary for greater organization and effectiveness.

Table 3. Communication style assessment - Activity 1E

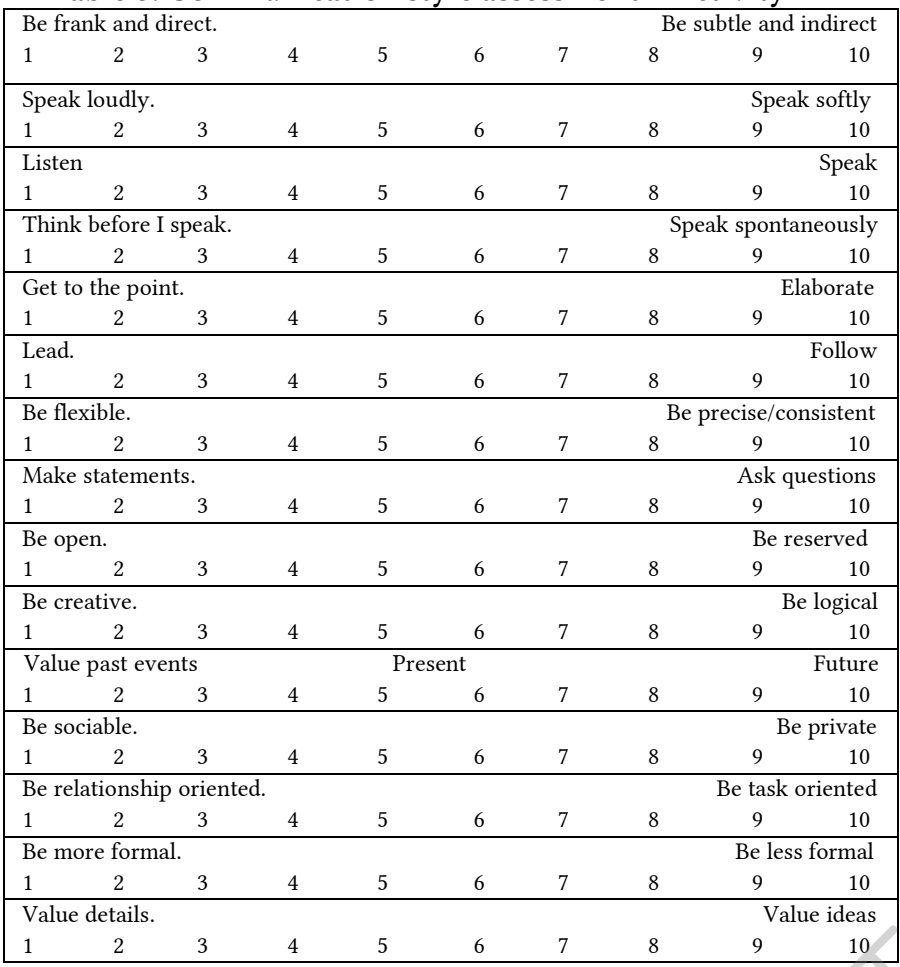

Goal J: Develop action or implementation plan.

Mentoring session debriefs - Activity 2E: The central objective of this tool is to make the mentee aware of their weak and strong points in order to frame them in the areas of work. In order to elaborate a plan of action, this tool is oriented to help the mentee to focus on an action to be carried out or on a topic to be developed.

Stage 3: Assessing and Closing.

Goal K: Assess whether development goals have been met. Complete personal and professional accomplishments tool. Activity 3A: This tool helps to identify gaps between performance and individual mentoring goals. Its main purpose is to identify why theses gaps exist and make corrections. The D-COM Model (a framework for evaluating and transforming companies to achieve sustained high performance) [52] is the accomplishment tool to apply in this stage. It includes some key factors that can help pinpoint where the mentor may need to make adjustments. $D$-COM stands for Direction, Competence, Opportunity, and Motivation.

Goal L: Provide feedback to one another on the effectiveness of the partnership.

Participate in experience exchange celebration. Complete final online evaluation of mentoring relationship and process Activity 3B: This tool helps to decide how mentees are most effective (as perceived by others), identify areas for growth and development, consider other points of view.

\section{Conclusions}

The skills and tools possessed by a mentor are a very important part of their professional practice, these include observation, providing good feedback, and the ability to maintain harmony with the mentee, and so on. In this way, assertiveness is very important to establish a communication link with the mentee [37].

The way to obtain information is also key to achieving satisfactory results without the interlocutor feeling assaulted or vulnerable through the mentoring process. That is why it is very important to show empathy towards the other and to use motivational resources to encourage a positive and evolutionary change.

Using a toolkit provides numerous benefits in the mentoring sessions but also entails certain inherent dangers. These tools combined with the practical exercises, techniques, and academic dynamics are proposed to use with the mentee in the sessions. Mentoring takes tools that come from different disciplines: coaching, Neuro-linguistic programming (NLP), therapy, business, the world of sports, socio-cultural animation, the field of education, literature and especially the creativity of the mentor and from the mentee to create a session that helps the mentee develop and advance towards achieving their goals [42].

These tools can be of great help in a session because they invite the mentee to experience from the visual, auditory, and kinesthetic aspects of learning. Its metaphorical component helps to generate awareness in the session itself. They serve as anchors and reflections for the mentee when he/she is away from the sessions to consider as they face the challenges of the environment in which they wish to advance [38]. In addition, they help mobilize and motivate mentees when they are challenged and uncertain how to face a particular situation.

There are numerous benefits of using tools but there are also some dangers which include:

- The tool becomes the center of the session. This means that the focus is placed on the tool and the mentor loses the mentee, and there is not an authentic connection. Rather, the session is more focused on the tool and its correct development than on what the mentee needs or says [51]. Listening to what happens in the session, including elements of respect and a genuine presence are key to avoiding this pitfall.

- Tools without purpose. The mentoring sessions were directed towards an objective (not only of process but of session). If the mentoring process becomes so focused on the tools rather than transaction of experience between the mentee, the mentee will grow frustrated feeling they lack a sense of direction at the conclusion of each session [40]. Mentors must remain mindful that the mentoring process is one that requires mentees be provided a sense of direction that is aligned with his or her values systems and intrinsic motivations.

- Unrealistic expectations that utilizing tools along will be responsible for the desired change. Tools 
do not bring about changes; changes are made by mentees taking full ownership of their goals and remaining fully engaged in the execution of goals and strategies agreed upon by the mentor and mentee [50]. Similar to how a hammer does not drive nails, the nails are nailed by the person with the hammer, without the person the hammer is useless.

The toolkit is the focus of the author thesis, where the tools will be fully evaluated becoming one on future directions to identify additional information.

\section{ACKNOWLEDGMENTS}

This research study has been carried out within Education in Knowledge Society $\mathrm{PhD}$ Programme of the University of Salamanca [53-56].

\section{REFERENCES}

[1] Francisco Acosta Hernández, Antonio J. Briones Peñalver, \& Francisco Campuzano Bolarín. 2017. La Administración Relacional mediante etutorización, una herramienta de ayuda a las nuevas empresas. Small Business International Review, 1(1),35-52. https://doi.org/10.26784/sbir.v1i1.5

[2] Kerstin Arnesson, \& Gunilla Albinsson. 2017. Mentorship - a pedagogical method for integration of theory and practice in higher education,Nordic Journal of Studies in Educational Policy, 3:3, 202217, DOI: $10.1080 / 20020317.2017 .1379346$

[3] Ridhi Arora, \& Santosh Rangnekar. 2014. Workplace mentoring and career resilience: An empirical test. The Psychologist-Manager fournal, 17(3), 205220. http://dx.doi.org/10.1037/mgr0000021

[4] Jessica Aspfors, \& Göran Fransson. 2015. Research on mentor education for mentors of newly qualified teachers: A qualitative meta-synthesis. Teaching and teacher education, 48, 75-86. https://doi.org/10.1016/j.tate.2015.02.004

[5] Megan Aylor, Mario Cruz, Aditee Narayan, Clifton Yu, Joseph Lopreiato, Keith J. Mann, Rhonda Graves Acholonu, Teri Lee Turner, Janet R. Serwint, Theodore Charles Sectisch, Marsha S. Anderson, \& Nancy D. Spector. 2016 Optimizing Your Mentoring Relationship: A Toolkit for Mentors and Mentees. MedEdPORTAL: the journal of teaching and learning resources, 12. DOI: $10.15766 / \mathrm{mep} \mathrm{2374-8265.10459}$

[6] Susan D. Ballard. 2013. Mentoring in the 21st century. Knowledge Quest, 41(4), 4-6.

[7] Jeffrey L. Bernstein, Andrew P. Abad, Benjamin C. Bower, Sara E. Box, Hailey L. Huckestein, Steven M. Mikulic, \& Brian E. Walsh. 2016. How Students, Collaborating as Peer Mentors, Enabled an Audacious GroupBased Project. New Directions for Teaching Gand learning, 2016(148), 25-37. https://doi.org/10.1002/tl.20207

[8] Abour H. Cherif, Maris Roze, \& Stefanos Gialamas. 2016. The Free Classroom Creative Assignment: leveraging student strengths to enhance learning. The International Schools fournal, 35(2), 57.

[9] Omer Cloutier, Laura Felusiak, Calvin Hill, \& Enda Jean Pemberton-Jones. 2015. The Importance of Developing Strategies for Employee Retention. Journal of Leadership, Accountability \& Ethics, 12(2). Retrieved from http://www.na-businesspress.com/JLAE/PembertonJonesEJ_Web12_2_.pdf

[10] Frank Crasborn, Paul Hennissen, Niels Brouwer, Fred Korthagen, \& Theo Bergen. 2008. Promoting versatility in mentor teachers' use of supervisory skills. Teaching and teacher education, 24(3), 499-514. https://doi.org/10.1016/j.tate.2007.05.001

[11] Bert Creemers, \& Leonidas Kyriakides. 2015. Developing, testing, and using theoretical models for promoting quality in education. School Effectiveness and School Improvement, 26(1), 102-119. https://doi.org/10.1080/09243453.2013.869233

[12] Norma L. Columbaro. 2009. E-Mentoring possibilities for online doctoral students: A literature review. Adult Learning, 20(3-4), 9-15. https://doi.org/10.1177/104515950902000305

[13] Jane E. Dutton, \& Emily D. Heaphy. 2003. The power of high-quality connections. Positive organizational scholarship: Foundations of a new discipline, 3, 263-278.
[14] Lillian T. Eby, Marcus Butts, Angie Lockwood, \& Shana A Simon. 2004. Protègès negative mentoring experiences: Construct development and nomo logical validation. Personnel Psychology, 57, 411447. https://doi.org/10.1111/j.1744-6570.2004.tb02496.x

[15] Gizem Erdem, David L. DuBois, Simon Larose, David De Wit, \& Ellen L. Lipman. 2016. Mentoring relationships, positive development, youth emotional and behavioral problems: Investigation of a mediational model. fournal of Community Psychology, 44(4), 464-483. https://doi.org/10.1002/jcop.21782

[16] Jessica Aspfors, \& Göran Fransson (2015). Research on mentor education for mentors of newly qualified teachers: A qualitative meta-synthesis. Teaching and teacher education, 48, 75-86. https://doi.org/10.1016/j.tate.2015.02.004

[17] Hazel Ferguson, \& Katherine L. Wheat. 2015. Early career academic mentoring using Twitter: the case of\# ECRchat. Fournal of higher education policy and management, 37(1), 3-13. http://dx.doi.org/10.1080/1360080X.2014.991533

[18] Judie M. Gannon, \& Angela Maher. 2012. Developing tomorrow's talent: The case of an undergraduate mentoring programme. Education+ Training, 54(6), 440-455. https://doi.org/10.1108/00400911211254244

[19] Thomas Garavan, Ronan Carbery, \& Andrew Rock. 2012. Mapping talent development: definition, scope and architecture. European journal of training and development, 36(1), 5-24. https://doi.org/10.1108/03090591211192601

[20] Donald E. Gibson. 2004. Role models in career development: New directions for theory and research. fournal of vocational behavior, 65(1), 134-156. https://doi.org/10.1016/S0001-8791(03)00051-4

[21] Merita Hoxha. 2016. The mentor and the student-teacher: An important and delicate relationship. Journal of Educational and Social Research, 6(3), 87. DOI: $10.5901 /$ jesr.2016.v6n3p87

[22] Changya Hu, Sheng Wang, Yu-Hsuan Wang, Cheng Chen, \& Ding-Yu Jiang. 2016. Understanding attraction in formal mentoring relationships from an affective perspective. Journal of Vocational Behavior, 94, 104-113. https://doi.org/10.1016/j.jvb.2016.02.007

[23] Peter Hudson. 2016. Forming the mentor-mentee relationship. Mentoring \& tutoring: partnership in learning, 24(1), 30-43. DOI: $\underline{10.1080 / 13611267.2016 .1163637}$

[24] Minna Körkkö, Outi Kyrö-Ämmälä, \& Tinja Turunen. 2016. Professional development through reflection in teacher education. Teaching and Teacher Education, 55, 198-206. https://doi.org/10.1016/j.tate.2016.01.014

[25] Ye Hoon Lee, \& Packiamathan Chelladurai. 2018. Emotional intelligence, emotional labor, coach burnout, job satisfaction, and turnover intention in sport leadership. European Sport Management Quarterly, 18(4), 393-412. DOI: $10.1080 / 16184742.2017 .1406971$

[26] Laura G. Lunsford, Vicki Baker, Kimberly A. Griffin, \& W. Brand Johnson. 2013. Mentoring: A typology of costs for higher education faculty. Mentoring \& Tutoring: Partnership in Learning, 21(2), 126-149. https://doi.org/10.1080/13611267.2013.813725

[27] Vincent Lyons, \& Donna Pastore. 2016. Tools for a formal mentoring program: A guide every mentee in coaching can use. Physical Educator, 73(1), 1-14 http://dx.doi.org/10.18666/TPE-2016-V73-I1-5931

[28] Carol A. Mancuso, Jessica R. Berman, Laura Robbins, \& Sthepen A. Paget. 2019. What Mentors Tell Us About Acknowledging Effort and Sustaining Academic Research Mentoring: A Qualitative Study. Fournal of Continuing Education in the Health Professions, 39(1), 29-35. doi: 10.1097/CEH.0000000000000234

[29] Jason Martin. 2015. Transformational and transactional leadership: An exploration of gender, experience, and institution type. portal: Libraries and the Academy, 15(2), 331-351. https://doi.org/10.1353/pla.2015.0015

[30] Susan R. Meier. 2013. Concept analysis of mentoring. Advances in Neonatal Care, 13(5), 341-345. doi: 10.1097/ANC.0b013e3182a14ca4

[31] Melissa E. Mitchell, Lillian T. Eby, \& Belle Rose Ragins. 2015. My mentor, myself: Antecedents and outcomes of perceived similarity in mentoring relationships. Fournal of Vocational Behavior, 89, 1-9. https://doi.org/10.1016/j.jvb.2015.04.008

[32] Beronda L. Montgomery. 2016. Successful STEM mentoring initiatives for underrepresented students: A research-based guide for faculty and administrators. Mentoring \& Tutoring: Partnership in Learning, 24(5), 471476. DOI: $10.1080 / 13611267.2016 .1270901$

[33] Carolyn Y. Nicholson, Larry D. Compeau, \& Rajesh Sethi. 2001. The role of interpersonal liking in building trust in long-term channel relationships. Journal of the Academy of Marketing Science,29(1), 3. https://doi.org/10.1177/0092070301291001 
[34] Paula Olszewski-Kubilius, Rena F. Subotnik, \& Frank C. Worrell. 2015. Conceptualizations of giftedness and the development of talent: Implications for counselors. Journal of Counseling \& Development, 93(2), 143152. https://doi.org/10.1002/j.1556-6676.2015.00190.x

[35] John R. Reynolds, \& Michael Parrish. 2018. Natural mentors, Social class, and college success. American journal of community psychology, 61(1-2), 179190. https://doi.org/10.1002/ajcp.12209

[36] Patricia A. Tabloski. 2016. Setting the stage for success: Mentoring and leadership development. fournal of Professional Nursing, 32(5), S54-S58. https://doi.org/10.1016/j.profnurs.2016.03.003

[37] Roman Taraban, \& Erin Logue. 2012. Academic factors that affect undergraduate research experiences. Fournal of Educational Psychology, 104(2), 499-514. https://psycnet.apa.org/doi/10.1037/a0026851

[38] J. Denard Thomas, Laura Gail Lunsford \& Helena A. Rodrigues. 2015. Early career academic staff support: evaluating mentoring networks, Journal of Higher Education Policy and Management, 37:3, 320329. 10.1080/1360080X.2015.1034426

[39] Renne Thompson, Debra M. Wolf, \& Janice M. Sabatine. 2012. Mentoring and coaching: A model guiding professional nurses to executive success. fournal of nursing administration, 42(11), 536-541. 10.1097/NNA.0b013e31827144ea

[40] Harold Tinoco-Giraldo. 2018. Diseño de un programa de e-mentoring a partir del análisis de competencias adquiridas por los estudiantes de práctica empresarial del programa de mercadeo. Lúmina, (19): 48 - 70 . $\underline{\text { 10.30554/lúmina.19.2782.2018 }}$

[41] Nuria Gisbert Trejo, Luciano María Azpizu Canivell, Jon Landeta Rodríguez, Eneka Albizu Gallestegi, \& Pilar Fernández Ferrín. 2018. Mentoring en los Colegios profesionales: una herramienta para el desarrollo de carrera. DYNA, 93(3), 257-261. http://dx.doi.org/10.6036/8478

[42] Lauren Weiner Vaknin, \& Marilee J. Bresciani. 2013. Implementing quality service-learning programs in Community Colleges. Community College fournal of Research and Practica, 37(12), 979-989. https://doi.org/10.1080/10668926.2010.515515

[43] Gisbert Van Ginkel, Nico Verloop, \& Eddie Denessen. 2016. Why mentor? Linking mentor teachers' motivations to their mentoring conceptions. Teachers and teaching, 22(1), 101-116. https://doi.org/10.1080/13540602.2015.1023031

[44] Jian Wang, \& Sandra J. Odell. 2002. Mentored learning to teach according to standards-based reform: A critical review. Review of Educational Research, 72, 481-546. https://doi.org/10.3102\%2F00346543072003481

[45] Leah Wasburn-Moses, \& Amity Noltemeyer. 2018. Effectiveness of Campus Mentors, an alternative school-university partnership. Preventing School Failure: Alternative Education for Children and Youth, 62(3), 190-197. https://doi.org/10.1080/1045988X.2017.1413534
[46] Frankie J. Weinberg. 2019. How and When Is Role Modeling Effective? The Influence of Mentee Professional Identity on Mentoring Dynamics and Personal Learning Outcomes. Group \& Organization Management, 44(2), 425477. DOI: $10.1177 / 1059601119838689$

[47] Francisco J. García-Peñalvo, \& Antonio Miguel Seoane Pardo. 2015. An updated review of the concept of eLearning. Tenth anniversary. Education in the Knowledge Society, 16(1), 119-144. DOI: http://dx.doi.org/10.14201/eks2015161119144.

[48] Begoña Gros, B., \& Francisco J. García-Peñalvo. 2016. Future trends in the design strategies and technological affordances of e-learning. Learning, Design, and Technology: An International Compendium of Theory, Research, Practice, and Policy, 1-23. DOI:10.1007/978-3-319-17727-4_67-1.

[49] Francisco Mora-Vicarioli, \& Kathya Salazar-Blanco. 2019. Aplicabilidad de las pedagogías emergentes en el e-learning. Revista Ensayos Pedagógicos, 14(1), 125-159. DOI: https://doi.org/10.15359/rep.14-1.6

[50] Antonio Miguel Seoane-Pardo. 2014. Formalización de un modelo de formación online basado en el factor humano y la presencia docente mediante un lenguaje de patrón. PhD. Programa de Doctorado en Formación en la Sociedad del Conocimiento. Universidad de Salamanca. https://goo.gl/sNrkHu

[51] Kimberly Nicole Rowland. 2012. E-mentoring: An innovative twist to traditional mentoring. Journal of technology management \& innovation, 7(1), 228-237. http://dx.doi.org/10.4067/S071827242012000100015

[52] Ahmed A. Wadee, \& Anshu Padayachee. 2017. Higher Education: catalysts for the development of an entrepreneurial ecosystem, or... are we the weakest link? Science, Technology and Society, 22(2), 284-309. https://doi.org/10.1177/0971721817702290

[53] F. J. García-Peñalvo. 2014. Formación en la sociedad del conocimiento, un programa de doctorado con una perspectiva interdisciplinar. Education in the Knowledge Society 15, 1, 4-9.

[54] F. J. García-Peñalvo, M. S. Ramírez-Montoya, and A. García-Holgado. 2017. TEEM 2017 Doctoral Consortium Track. In Fifth International Conference on Technological Ecosystems for Enhancing Multiculturality (TEEM'17) (Cádiz, Spain, October 18-20, 2017) J.M. Dodero, M.S. Ibarra Sáiz and I. Ruiz Rube Eds. ACM, New York, NY, USA, Article 93 Rube Eds. ACM, New
DOI:10.1145/3144826.3145440.

[55] F. J. García-Peñalvo, A. García- Holgado, and M. S. Ramírez-Montoya. 2018 The PhD Corner: TEEM 2018 Doctoral Consortium. In TEEM'18 Proceeding of the Sixth International Conference on Technological Ecosystems for Enhancing Multiculturality (Salamanca, Spain, October 24th-26th, 2018), F.J. García-Peñalvo Ed. ACM, New York, NY, USA, 979-983. DOI: $10.1145 / 3284179.3284343$

[56] F. J. García-Peñalvo. 2018. Edición 2018-2019 del Kick-off del Programa de Doctorado "Formación en la Sociedad del Conocimiento". In Proceedings of the Seminarios del Programa de Doctorado en Formación en la Sociedad del Conocimiento (23 de octubre de 2018) (Salamanca, España2018). Instituto Universitario de Ciencias de la Educación. 